\title{
The Indo-Pacific Sergeant Abudefduf vaigiensis (Quoy \& Gaimard, 1825) (Perciformes: Pomacentridae) in Libya, South-Central Mediterranean Sea
}

\author{
David Osca ${ }^{1}$, Valentina Tanduo ${ }^{1}$, Francesco Tiralongo ${ }^{2,3}$, Ioannis Giovos ${ }^{4}$, \\ Sara A. A. Almabruk ${ }^{5}$, Fabio Crocetta ${ }^{1, *(D)}$ and Jamila Rizgalla ${ }^{6}$ \\ 1 Department of Integrative Marine Ecology, Stazione Zoologica Anton Dohrn, Villa Comunale, \\ I-80121 Napoli, Italy; david.osca@szn.it (D.O.); valentina.tanduo@libero.it (V.T.) \\ 2 Ente Fauna Marina Mediterranean, Scientific Organization for Research and Conservation of Marine \\ Biodiversity, I-96012 Avola, Italy; francesco.tiralongo@unict.it \\ 3 Department of Biological, Geological and Environmental Science, University of Catania, \\ I-95131 Catania, Italy \\ 4 iSea, Environmental Organization for the Preservation of the Aquatic Ecosystems, \\ GR-55438 Thessaloniki, Greece; ioannis.giovos@isea.com.gr \\ 5 Zoology Department, Faculty of Science, Omar Al-Mokhtar University, P.O. Box 919 El Bayda, Libya; \\ sara.almabruk@omu.edu.ly \\ 6 Department of Aquaculture, Faculty of Agriculture, University of Tripoli, P.O. Box 13275 Tripoli, Libya; \\ jamilarizgalla@gmail.com \\ * Correspondence: fabio.crocetta@szn.it
}

Received: 29 November 2019; Accepted: 21 December 2019; Published: 24 December 2019

\begin{abstract}
The Indo-Pacific Sergeant Abudefduf vaigiensis (Quoy \& Gaimard, 1825) (Chordata: Pisces: Actinopterygii: Perciformes: Pomacentridae) is first recorded in the south-central Mediterranean Sea (Libya), based on the external morphology and the barcoding of a fragment of the cytochrome c oxidase subunit I gene. Present sightings from field surveys and social media include juveniles, sub-adults, and a single adult specimen, suggesting that the species is now established in Libyan waters. No certainties occur regarding timing and possible pathway of arrival of this species in the area, and it may have simply gone undetected for years. The joint effort of field studies and citizen science projects in collaboration with international organizations continues shedding light on bioinvasions in Libya, with valuable outcomes for the Mediterranean marine biology as a whole.
\end{abstract}

Keywords: coastal monitoring; citizen science; alien species; bioinvasions; damselfishes

\section{Introduction}

Biological pollution is a common phenomenon worldwide. Although marine invasions have been widely documented all over the world [1], they are very relevant in the Mediterranean Sea, where native species are often even outnumbered by congeneric or confamilial taxa [2]. The family Pomacentridae Bonaparte, 1831 in the Mediterranean Sea, as an example, includes a single native species, Chromis chromis (Linnaeus, 1758), and seven additional alien or cryptogenic taxa, namely Abudefduf hoefleri (Steindachner, 1881), Abudefduf saxatilis (Linnaeus, 1758), Abudefduf sexfasciatus (Lacepède, 1801), Abudefduf vaigiensis (Quoy \& Gaimard, 1825), Chrysiptera cyanea (Quoy \& Gaimard, 1825), Chrysiptera hemicyanea (Weber, 1913), and Stegastes variabilis (Castelnau, 1855) (Table 1, Figure 1). 
Table 1. Records of alien and cryptogenic taxa belonging to the family Pomacentridae Bonaparte, 1831 from the Mediterranean Sea, with origin, country and locality with coordinates, year of first sighting, number of specimens $(\mathrm{N})$, environment, method of observation, and references (R) as listed in literature (see also Figure 1). Abbreviations used: AO—Eastern and Western Atlantic Ocean; EA-Eastern Atlantic; IP—Indo-Pacific; IWP-Indo-West Pacific; WA-Western Atlantic.

\begin{tabular}{|c|c|c|c|c|c|c|c|}
\hline Taxon & Origin & Country and Locality & Year & $\mathbf{N}$ & Environment & Method & $\mathbf{R}$ \\
\hline $\begin{array}{l}\text { Abudefduf hoefleri } \\
\text { (Steindachner, 1881) }\end{array}$ & EA & $\begin{array}{c}\text { Malta, Delimara } \\
35.8352^{\circ} \mathrm{N}, 14.5626^{\circ} \mathrm{E}\end{array}$ & 2014 & 1 & shallow coastal waters & sampled & [3] \\
\hline \multirow{5}{*}{$\begin{array}{l}\text { Abudefduf saxatilis } \\
\text { (Linnaeus, 1758) }\end{array}$} & \multirow{5}{*}{$\mathrm{AO}$} & $\begin{array}{c}\text { Spain, Tarragona } \\
41.1310^{\circ} \mathrm{N}, 1.3704^{\circ} \mathrm{E}\end{array}$ & 2009 & 1 & $2 \mathrm{~m}$ & observed & {$[4]$} \\
\hline & & $\begin{array}{l}\text { Malta, Valletta Grand Harbour } \\
\quad 35.5337^{\circ} \mathrm{N}, 14.3052^{\circ} \mathrm{E}\end{array}$ & 2013 & $6-7$ & $\begin{array}{l}\text { close to the cruise-ship } \\
\text { passenger terminal }\end{array}$ & observed & [5] \\
\hline & & $\begin{array}{c}\text { Israel, Sdot-Yam } \\
32.2932^{\circ} \mathrm{N}, 34.5315^{\circ} \mathrm{E}\end{array}$ & 2013 & 10 & $\begin{array}{c}\text { shallow rocky reef } \\
1.5-2 \mathrm{~m}\end{array}$ & sampled & [6] \\
\hline & & $\begin{array}{l}\text { Malta, Valletta Grand Harbour } \\
\quad 35.8982^{\circ} \mathrm{N}, 14.5206^{\circ} \mathrm{E}\end{array}$ & 2013-2014 & 3 & - & observed & [7] \\
\hline & & $\begin{array}{l}\text { Turkey, Çandarlı Bay } \\
38.5144^{\circ} \mathrm{N}, 26.5251^{\circ} \mathrm{E}\end{array}$ & 2016 & 1 & $1-3 \mathrm{~m}$ & observed & [8] \\
\hline $\begin{array}{l}\text { Abudefduf sexfasciatus } \\
\text { (Lacepède, 1801) }\end{array}$ & IP & $\begin{array}{c}\text { Greece, Sounio } \\
37.6773^{\circ} \mathrm{N}, 24.0554^{\circ} \mathrm{E}\end{array}$ & 2017 & 1 & $2 \mathrm{~m}$ & observed & [9] \\
\hline \multirow{6}{*}{$\begin{array}{c}\text { Abudefduf vaigiensis } \\
\text { (Quoy \& Gaimard, 1825) }\end{array}$} & \multirow{6}{*}{ IP } & $\begin{array}{l}\text { Italy, Gulf of Naples } \\
40.4754^{\circ} \mathrm{N}, 14.1230^{\circ} \mathrm{E}\end{array}$ & 1957 & 1 & $100 \mathrm{~m}$ from seashore & sampled & [10] \\
\hline & & $\begin{array}{l}\text { Israel, Rosh Ha'Nikra } \\
33.0885^{\circ} \mathrm{N}, 35.1053^{\circ} \mathrm{E}\end{array}$ & 1997 & 1 & $\begin{array}{l}\text { littoral platform } \\
1-2 \mathrm{~m}\end{array}$ & sampled & [11] \\
\hline & & $\begin{array}{c}\text { Italy, Gulf of Genoa } \\
44.1510^{\circ} \mathrm{N}, 9.2541^{\circ} \mathrm{E}\end{array}$ & 1998 & 1 & $\begin{array}{l}\text { vertical rocky wall } \\
2 \mathrm{~m}\end{array}$ & observed & [12] \\
\hline & & $\begin{array}{l}\text { Malta, Valletta Grand Harbour } \\
\quad 35.8982^{\circ} \mathrm{N}, 14.5206^{\circ} \mathrm{E}\end{array}$ & 2013 & 2 & - & sampled & [7] \\
\hline & & $\begin{array}{l}\text { Malta, Valletta Grand Harbour and nearby } \\
35.9029^{\circ} \mathrm{N}, 14.5205^{\circ} \mathrm{E}\end{array}$ & 2015 & 6 & - & sampled & [7] \\
\hline & & $\begin{array}{c}\text { Lebanon } \\
\sim 34.0085^{\circ} \mathrm{N}, 35.0211^{\circ} \mathrm{E}\end{array}$ & $\leq 2015$ & 1 & - & sampled & [13] \\
\hline $\begin{array}{c}\text { Chrysiptera cyanea } \\
\text { (Quoy \& Gaimard, 1825) }\end{array}$ & IWP & $\begin{array}{c}\text { Slovenia, Portoroz } \\
45.3048^{\circ} \mathrm{N}, 13.3459^{\circ} \mathrm{E}\end{array}$ & 2013 & 1 & salt storehouse & observed & [14] \\
\hline
\end{tabular}


Table 1. Cont.

\begin{tabular}{|c|c|c|c|c|c|c|c|}
\hline Taxon & Origin & Country and Locality & Year & $\mathbf{N}$ & Environment & Method & $\mathbf{R}$ \\
\hline $\begin{array}{l}\text { Chrysiptera hemicyanea } \\
\text { (Weber, 1913) }\end{array}$ & IWP & $\begin{array}{l}\text { Malta, Marsaxmett Harbour } \\
35.5445^{\circ} \mathrm{N}, 14.3011^{\circ} \mathrm{E}\end{array}$ & 2017 & 1 & $\begin{array}{l}\text { large rocks and boulders } \\
\qquad 2 \mathrm{~m}\end{array}$ & observed & [15] \\
\hline $\begin{array}{l}\text { Stegastes variabilis } \\
\text { (Castelnau, 1855) }\end{array}$ & WA & $\begin{array}{c}\text { Malta, Senglea } \\
35.8910^{\circ} \mathrm{N}, 14.5142^{\circ} \mathrm{E}\end{array}$ & 2013 & 1 & $\begin{array}{l}\text { waterfront } \\
2 \mathrm{~m}\end{array}$ & sampled & [16] \\
\hline
\end{tabular}

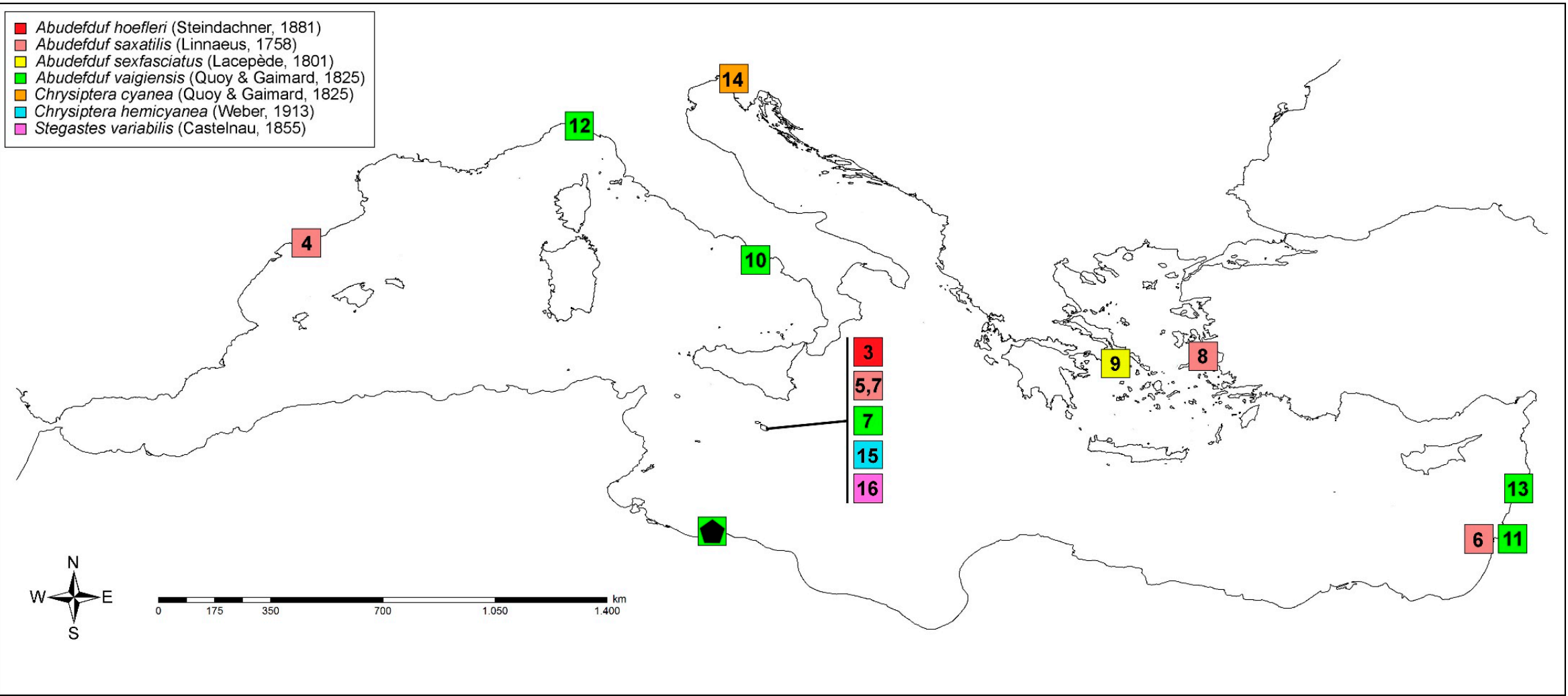

Figure 1. Sightings of alien and cryptogenic taxa belonging to the family Pomacentridae Bonaparte, 1831 from the Mediterranean Sea. Numbers refer to literature records (see also Table 1). Black pentagon refers to present record. 
The majority of these species are known from the Mediterranean basin based on single records, some of which were obtained through social media and citizen scientist projects [4,9]. However, the Sergeant-major (A. saxatilis) and the Indo-Pacific Sergeant (A. vaigiensis) were recorded from larger parts of the Mediterranean Sea for decades, with $A$. vaigiensis being first recorded in Italy more than 60 years ago [4-7,10-13]. In addition, despite putative distinct colour-pattern features should allow their easy visual identification (according to the literature, in A. saxatilis the fifth vertical dark bar extends without gap on the posterior margin of the dorsal fin, whereas in A. vaigiensis it has a gap between it and the dorsal fin; in A. saxatilis, two black spots are present on the caudal peduncle, whereas they are absent in $A$. vaigiensis $[6,7,17,18])$, the local distribution and state of these two species still remain ambiguous due to misidentifications between the two congeners, with some researchers even doubting the presence of consistent meristic or morphometric differences (Gerald R. Allen, Western Australian Museum, Perth, Australia; pers. comm. [5]). In this light, recent confirmed records from the Mediterranean Sea only relied on barcoding of selected specimens $[6,7,13]$.

The introduction pathway in the Mediterranean Sea of both A. saxatilis and A. vaigiensis also remains unclear, an uncertainty which is partly due to the patchy distribution with long distances between the observation points (Table 1 and Figure 1). Several pathways were proposed for A. saxatilis, including aquarium release, ship transport, or even natural range expansion through the Gibraltar Strait $[4,5,19]$, and the same holds for $A$. vaigiensis, whose proposed pathways included aquarium release, ship transport, or Lessepsian invasion through the Suez Canal [11,13,19-21].

The aim of the present paper is to first report the presence of A. vaigiensis in south-central Mediterranean Sea (Libya) based on external morphology and barcoding of a fragment of the cytochrome c oxidase subunit I (COI) gene. In addition, we here highlight the additional observation of an Abudefduf specimen matching the morphological characters of $A$. saxatilis, thus suggesting that also the occurrence of $A$. saxatilis in Libya may be possible.

\section{Materials and Methods}

The data reported in the present paper fall within the framework of an ongoing project that aims at monitoring the marine biodiversity in Libya by integrating information gained from field surveys and social media (citizen science projects and mining Facebook ${ }^{\mathrm{TM}}$ posts).

Field surveys were conducted in two stages, from 14th June to 7th November 2018 and from 5th May to 29th October 2019, in an area of approximately 90 hectares with a $2.2 \mathrm{~km}$ long coastline in a natural shallow water bay, situated $12 \mathrm{~km}$ west of Tripoli Harbour and known as "Regatta" or "Magribi Arabic Touristic Village". Along this coastline, there is a shallow water natural bay $\left(32.8539^{\circ} \mathrm{N}\right.$, $13.0543^{\circ} \mathrm{E}$ ) formed between two islands subjected to tidal movements. The natural bay consists of sandy and rocky substrates. Snorkel surveys were undertaken, weather permitting, at several locations within the bay and along the island margins, and consisted of a consecutive series of 2-6-h-long snorkel dives up to $2 \mathrm{~m}$ depth. Pictures and short pieces of footage were taken in situ using Tough TG-3 and TG-4 Olympus underwater cameras. A single Abudefduf specimen was taken with the help of a hand net, and then placed in $90-96 \%$ ethanol for preservation and further study.

Six Facebook ${ }^{\mathrm{TM}}$ groups with an interest in both recreational and professional fishing were monitored daily for recent postings from January 2018 to September 2019. Furthermore, relevant posts prior to these dates and extending back to 2012 were also screened. Owners of relevant posts were contacted to obtain information on posted material, and permission was sought from the owners of the Facebook ${ }^{\mathrm{TM}}$ post.

Genomic DNA of the single Abudefduf specimen sampled was extracted from the caudal fin by using the NucleoSpin ${ }^{\circledR}$ Tissue (Macherey-Nagel) kit, following the manufacturer's protocol. Partial sequence of the COI gene was amplified using the primers developed by Baldwin et al. [22]: forward - FISH-BCL: 5' -TCAACYAATCAYAAAGATATYGGCAC-3'; reverse - FISH-BCH: 5'-TAAACTTCAGGGTGACCAAAAAATCA-3'. The polymerase chain reaction (PCR) was conducted in $25 \mu \mathrm{L}$ volume reaction, containing $2.5 \mu \mathrm{L}$ of Roche buffer $(10 \times), 2.5 \mu \mathrm{L}(2 \mathrm{mM})$ of dNTPack Mixture 
(Roche), $2 \mu \mathrm{L}$ each of forward and reverse primers, $0.25 \mu \mathrm{L}(5 \mathrm{U} / \mu \mathrm{L})$ of Roche Taq DNA polymerase, $1 \mu \mathrm{L}$ of DNA $(15 \mathrm{ng} / \mu \mathrm{L})$ and sterilized distilled water up to $25 \mu \mathrm{L}$. Amplification was performed with an initial denaturation for $5 \mathrm{~min}$ at $95^{\circ} \mathrm{C}$, followed by 39 cycles of $1 \mathrm{~min}$ at $95^{\circ} \mathrm{C}, 1 \mathrm{~min}$ annealing at $47^{\circ} \mathrm{C}$ and $1 \mathrm{~min}$ at $72{ }^{\circ} \mathrm{C}$, with a final extension of $5 \mathrm{~min}$ at $72{ }^{\circ} \mathrm{C}$. The successful PCR product was purified and Sanger sequenced through an automated DNA sequencer (ABI PRISM 3730) at the Molecular Biology and Sequencing Service of SZN (Naples, Italy). Forward and reverse sequences obtained were assembled using Sequencher v. 5.0.1 (GeneCodes Co.) and compared with reference sequences from the entire NCBI nucleotide (NT) database using BLASTn [23] as to confirm the morphological identification and further verify the diagnostic nucleotide positions reported by Tsadok et al. [6].

\section{Results}

The field surveys held in Regatta yielded 6 different records, for a total of 9 specimens belonging to the genus Abudefduf (Table 2, Figure 2). However, some of these records may be based on the same individuals; in fact, from a cautious point of view, the records reported comprise at least 4 different specimens. The majority of the sightings (6) regarded specimens with an oval-shaped body, silvery-white belly in color with a yellow part around the base of the dorsal fin and five vertical conspicuous black bars, four on the trunk and the fifth located on the caudal peduncle, thus coinciding with morphological characters of $A$. vaigiensis. Among specimens showing such characters, a single juvenile individual ( $\mathrm{TL} \sim 2.2 \mathrm{~cm}$ ) was sampled on the 25th August 2019. All remaining individuals were only photographed, and these comprise at least a pair of larger individuals (TL $\sim 5 \mathrm{~cm}$ ) observed on the 18th September 2019. On the other hand, among the observed fishes, an individual showing morphological traits characteristic of $A$. saxatilis (and in particular two black spots on the caudal peduncle) was seen in three different days during October 2019 (Table 2, Figure 2).

Mining of Facebook ${ }^{\mathrm{TM}}$ posts backdated the presence of the genus Abudefduf in Libya to as early as the 10th July 2018, when a single adult specimen $(\mathrm{TL} \sim 10 \mathrm{~cm}$ ) of $A$. vaigiensis was sampled at shallow depths in Janzur, a locality $5 \mathrm{~km}$ west of Regatta, by a professional fisherman with a trammel net (Table 2, Figure 2).

Table 2. Records of specimens belonging to the genus Abudefduf Forsskål, 1775 from Libya, with locality, coordinates, date, method of observation, morphological identification, number of specimens (N), GenBank accession number, and figures (see Figure 2).

\begin{tabular}{|c|c|c|c|c|c|c|c|}
\hline Locality & Coordinates & Date & Method & $\begin{array}{l}\text { Morphological } \\
\text { Identification }\end{array}$ & $\mathbf{N}$ & GenBank & Figure \\
\hline Janzur & $\begin{array}{l}32.5028^{\circ} \mathrm{N} \\
13.0106^{\circ} \mathrm{E}\end{array}$ & 10.07.2018 & Facebook & A. vaigiensis & 1 & - & Figure 2A \\
\hline Regatta & $\begin{array}{l}32.8539^{\circ} \mathrm{N} \\
13.0543^{\circ} \mathrm{E}\end{array}$ & 7.09.2018 & field survey & A. vaigiensis & 1 & - & Figure 2B \\
\hline Regatta & $\begin{array}{l}32.8539^{\circ} \mathrm{N} \\
13.0543^{\circ} \mathrm{E}\end{array}$ & 25.08 .2019 & field survey & A. vaigiensis & 1 & MN852855 & Figure $2 \mathrm{C}-\mathrm{D}$ \\
\hline Regatta & $\begin{array}{l}32.8539^{\circ} \mathrm{N}, \\
13.0543^{\circ} \mathrm{E}\end{array}$ & 18.09 .2019 & field survey & A. vaigiensis & 2 & - & Figure $2 \mathrm{E}-\mathrm{F}$ \\
\hline Regatta & $\begin{array}{l}32.8539^{\circ} \mathrm{N} \\
13.0543^{\circ} \mathrm{E}\end{array}$ & 1.10 .2019 & field survey & A. cf. saxatilis & 1 & - & Figure 2G \\
\hline Regatta & $\begin{array}{c}32.8539^{\circ} \mathrm{N} \\
13.0543^{\circ} \mathrm{E}\end{array}$ & 19.10.2019 & field survey & $\begin{array}{c}\text { A. cf. saxatilis } \\
\text { and } A \text {. vaigiensis }\end{array}$ & 2 & - & - \\
\hline Regatta & $\begin{array}{l}32.8539^{\circ} \mathrm{N} \\
13.0543^{\circ} \mathrm{E}\end{array}$ & 29.10.2019 & field survey & $\begin{array}{l}\text { A. cf. saxatilis } \\
\text { and } A \text {. vaigiensis }\end{array}$ & 2 & - & Figure $2 \mathrm{H}$ \\
\hline
\end{tabular}




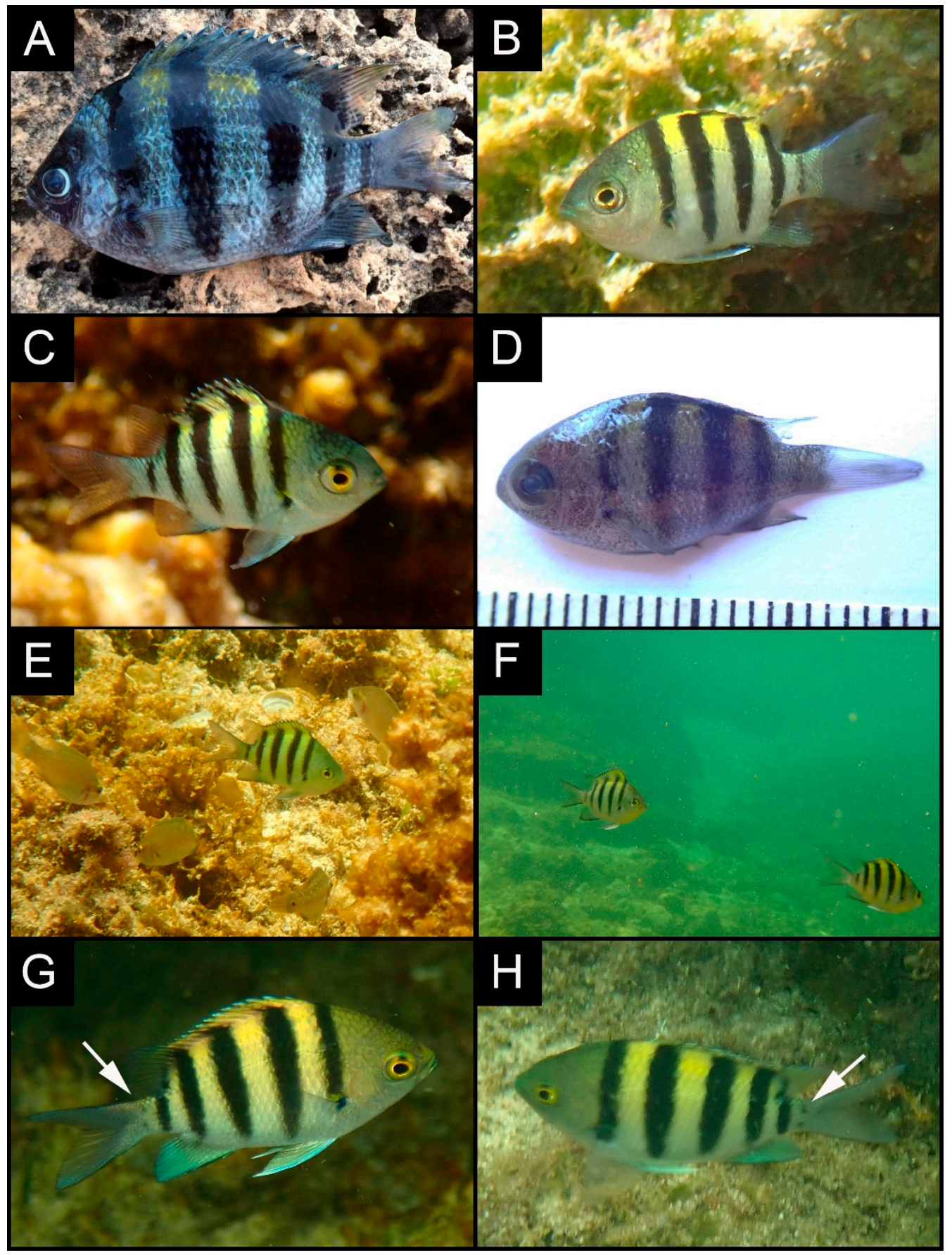

Figure 2. Specimens belonging to the genus Abudefduf Forsskål, 1775 reported in the present study from Libya. (A-F) Abudefduf vaigiensis. (G,H). Abudefduf cf. saxatilis. White arrows highlighting the two black spots on the caudal peduncle.

A 663 bp partial sequence of the COI gene was obtained. BLASTn queries generated sequences with a $100 \%$ identical score to $A$. vaigiensis, although high similarities (until $99.85 \%$ ) were also obtained with $A$. sexfasciatus. Our analysis on the diagnostic nucleotide positions revealed: i) two sequences identical to our (AP006016 with an unknown sampling locality, and MF123716 from the Gulf of Aqaba, Red Sea) [24,25]; ii) four sequences (MF123711, MF123713, MF123717, KF186627) from the Gulf of Aqaba and generally the Red Sea with a difference in position 346 [6,25]; iii) one sequence (FJ237571) from India with a difference in position 2 [26]; iv) two sequences (MF123715 and MF123714) from the 
Gulf of Aqaba with differences in positions 328 and 346 [25]; and v) one sequence (MF123712) from the Gulf of Aqaba with six differences in positions 58, 81, 105, 322, 346, and 484 [25].

\section{Discussion}

Molecular results obtained here are in agreement with data reported by Bertrand et al. [27], who noticed that an $A$. vaigiensis lineage was found to be nested within $A$. sexfasciatus in the mitochondrial gene tree, whereas both species were only found to be distinct based on nuclear information. Alternatively, another possibility is that some misidentifications may be at the basis of the sequences deposited in GenBank. However, A. vaigiensis and A. sexfasciatus clearly differ with regards morphology and color pattern, which definitively excludes $A$. sexfasciatus and confirms that the sequenced specimen from Libya belongs to $A$. vaigiensis. In addition, the 25 diagnostic positions reported by Tsadok et al. [6] to differentiate between $A$. vaigiensis and A. saxatilis are lowered here to 22 due to the presence of three $A$. saxatilis diagnostic nucleotide positions $(105,322$, and 484$)$ in the MF123712 sequence of $A$. vaigiensis.

To date, records of $A$. vaigiensis and of $A$. saxatilis were still unknown from the Mediterranean coastline of Africa, despite A. vaigiensis being first found in the central Mediterranean more than half a century ago [10], whereas $A$. saxatilis has become a commonly encountered taxon along the easternmost coastline of the Mediterranean Sea [6]. The present record of A. vaigiensis therefore fills a gap in the distribution of this taxon in the newly invaded area, and suggests that the species is now established in Libyan waters. With respect to its congeneric species A. saxatilis, records based only on morphology were published in Spain [4] and Malta [5,7]. If these records are true, then the sighting of an Atlantic species in the easternmost Mediterranean Sea [6] could be due to the presence of populations even in the western and central Mediterranean. In this light, its potential occurrence in Libya may also be possible; however, further field work and molecular analysis is needed to confirm that.

The new records reported here immediately raise the question of the origin of these specimens. Indeed, the most plausible hypothesis is that these fishes may have recently spread from nearby detected or yet-undetected populations. However, another plausible hypothesis is also that these and additional central Mediterranean populations may have simply gone undetected since years. In this light, the finding of a larger individual showing morphological features associated with reproductive activity, as well as the discovery of juveniles in two consecutive years, also strongly suggests the presence of this fish in the area well before the dates recorded here, and the possible presence of an undetected population in the area. Alternatively, these specimens may have been locally introduced through ship transport, and the findings in Janzur and Regatta may be the result of different intrusion attempts.

Alien invasion in the Mediterranean Sea is an increasing phenomenon, with reports of fishes held from various countries in the recent years (e.g., [28-32]). Libya, due to its geographic position, situated in the south-central Mediterranean Sea and possessing a coastline of $\sim 1770 \mathrm{~km}$, would constitute a key country to study the spreading of alien, cryptogenic, and newcomer species from the western Atlantic to the eastern Mediterranean and from the Red Sea to the western Mediterranean. However, it still lacks intensive systematic efforts for monitoring invasive marine species [33], a situation which is amplified by the wide political unrest in the region. Despite that, the number of alien species recorded in recent years is increasing thanks to field surveys, citizen-science projects, and international collaborations [33-44]. Therefore, if these joint efforts continue, the outcomes obtained will be valuable and useful for the Mediterranean marine biology as a whole.

Author Contributions: Conceptualization, D.O., F.C. and J.R.; methodology, D.O., F.C. and J.R.; lab work, D.O. and V.T.; field work, J.R.; bibliographic researches, D.O., V.T., F.T. and I.G.; social media data mining, J.R. and S.A.A.A.; writing-original draft preparation, D.O., F.C. and J.R.; writing-review and editing, D.O., V.T., F.T., I.G., S.A.A.A., F.C. and J.R.; funding acquisition, F.C. and J.R. All authors have read and agreed to the published version of the manuscript.

Funding: This research received no external funding. 
Acknowledgments: The fisherman Rabee Ahmad Sulatan provided information on the record in Janzur and allowed publication of the photo. The administration of Regatta granted free pass to conduct field surveys in 2019 and the security personnel provided a safe environment. Fedai provided assistance and an anonymous child helped catching the fish. Leticia Latanzy transported the Abudefduf specimen to Italy. We are grateful to all of them.

Conflicts of Interest: The authors declare no conflict of interest.

\section{References}

1. Molnar, J.L.; Gamboa, R.L.; Revenga, C.; Spalding, M.D. Assessing the global threat of invasive species to marine biodiversity. Front. Ecol. Environ. 2008, 6, 485-492. [CrossRef]

2. Coll, M.; Piroddi, C.; Steenbeek, J.; Kaschner, K.; Lasram, F.B.R.; Aguzzi, J.; Ballesteros, E.; Bianchi, C.N.; Corbera, J.; Dailianis, T.; et al. The biodiversity of the Mediterranean Sea: Estimates, Patterns, and Threats. PLoS ONE 2010, 5, e11842. [CrossRef]

3. Vella, A.; Vella, N.; Darmanin, S.A. The first record of the African Sergeant, Abudefduf hoefleri (Perciformes: Pomacentridae), in the Mediterranean Sea. Mar. Biodivers. Rec. 2016, 9, 15. [CrossRef]

4. Azzurro, E.; Broglio, E.; Maynou, F.; Bariche, M. Citizen science detects the undetected: The case of Abudefduf saxatilis from the Mediterranean Sea. Manag. Biol. Invasion. 2013, 4, 167-170. [CrossRef]

5. Deidun, A.; Castriota, L. First record of Abudefduf cfr saxatilis Linnaeus, 1758 (Perciformes: Pomacentridae) from the Maltese Islands (Central Mediterranean). Bioinvasions. Rec. 2014, 3, 53-56. [CrossRef]

6. Tsadok, R.; Rubin-Blum, M.; Shemesh, E.; Tchernov, D. On the occurrence and identification of Abudefduf saxatilis (Linnaeus, 1758) in the easternmost Mediterranean Sea. Aquat. Invasions 2015, 10, 101-105. [CrossRef]

7. Vella, A.; Agius Darmanin, S.; Vella, N. The first records of Indo-Pacific sergeant Abudefduf vaigiensis (Quoy \& Gaimard, 1825) and further notes on the occurrence of sergeant major A. saxatilis (Linnaeus, 1758) in Malta: Expanding populations of an invasive genus in the Mediterranean Sea. J. Black Sea 2016, 22, 1-15.

8. Bilecenoğlu, M. Two marine fish records of Liechtenstein's goby (Corcyrogobius liechtensteini) and the Atlantic originated sergeant major (Abudefduf saxatilis), new for the Turkish fauna. J. Black Sea 2016, 22, 259-265.

9. Giovos, I.; Bernardi, G.; Romanidis-Kyriakidis, G.; Marmara, D.; Kleitou, P. First records of the fish Abudefduf sexfasciatus (Lacepède, 1801) and Acanthurus sohal (Forsskål, 1775) in the Mediterranean Sea. Bioinvasions. Rec. 2018, 7, 205-210. [CrossRef]

10. Tardent, P. Capture d'un Abudefduf saxatilis vaigiensis Q. und G. (Pisces, Pomacentridae) dans le Golfe de Naples. Rev. Suisse Zool. 1959, 66, 347-351. [CrossRef]

11. Goren, M.; Galil, B.S. First record of the indo-pacific coral reef fish Abudefduf vaigiensis (Quoy \& Gaimard, 1825) in the Levant. Israel J. Zool. 1998, 44, 57-59. [CrossRef]

12. Vacchi, M.; Chiantore, M.C. Abudefduf vaigiensis (Quoy \& Gaimard, 1825): A tropical damselfish in Mediterranean Sea. Biol. Mar. Mediterr. 2000, 7, 841-843.

13. Bariche, M.; Torres, M.; Smith, C.; Sayar, N.; Azzurro, E.; Baker, R.; Bernardi, G. Red Sea fishes in the Mediterranean Sea: A preliminary investigation of a biological invasion using DNA barcoding. J. Biogeogr. 2015, 42, 2363-2373. [CrossRef]

14. Lipej, L.; Mavric, B.; Dulcic, J. First record of Chrysiptera cyanea (Quoy and Gaimard, 1825) (Perciformes: Pomacentridae) in the Mediterranean Sea. J. Appl. Ichtyol. 2014, 30, 1053-1055. [CrossRef]

15. Deidun, A.; De Catro, D.; Bariche, M. First record of the azure demoiselle, Chrysiptera hemicyanea (Actinopterygii: Perciformes: Pomacentridae), in the Mediterranean Sea. Acta Ichthyol. Piscat. 2018, 48, 87-91. [CrossRef]

16. Vella, A.; Darmanin, S.A.; Vella, N. Morphological and genetic barcoding study confirming the first Stegastes variabilis (Castelnau, 1855) report in the Mediterranean Sea. Mediterr. Mar. Sci. 2015, 16, 609-612. [CrossRef]

17. Allen, G.R. Damselfishes of the World; Mergus Publishers: Melle, Germany, 1991; p. 271.

18. Froese, R.; Pauly, D. FishBase (ver. 08/2019). Available online: www.fishbase.org (accessed on 18 November 2019).

19. Zenetos, A.; Çinar, M.E.; Crocetta, F.; Golani, D.; Rosso, A.; Servello, G.; Shenkar, N.; Turon, X.; Verlaque, M. Uncertainties and validation of alien species catalogues: The Mediterranean as an example. Estuar. Coast. Shelf Sci. 2017, 191, 171-187. [CrossRef]

20. Golani, D.; Orsi-Relini, L.; Massutí, E.; Quignard, J.P. CIESM Atlas of Exotic Species in the Mediterranean. Vol. 1. Fishes; CIESM Publications: Monaco, 2002; p. 254. 
21. Servello, G.; Andaloro, F.; Azzurro, E.; Castriota, L.; Catra, M.; Chiarore, A.; Crocetta, F.; D’Alessandro, M.; Denitto, F.; Froglia, C.; et al. Marine alien species in Italy: A contribution to the implementation of descriptor D2 of the marine strategy framework directive. Mediterr. Mar. Sci. 2019, 20,1-48. [CrossRef]

22. Baldwin, C.C.; Mounts, J.H.; Smith, D.G.; Weigt, L.A. Genetic identification and color descriptions of early life-history stages of Belizean Phaeoptyx and Astrapogon (Teleostei: Apogonidae) with comments on identification of adult Phaeoptyx. Zootaxa 2009, 1, 1-22. [CrossRef]

23. Morgulis, A.; Coulouris, G.; Raytselis, Y.; Madden, T.L.; Agarwala, R.; Schäffer, A.A. Database indexing for production MegaBLAST searches. Bioinformatics 2008, 24, 1757-1764. [CrossRef]

24. Mabuchi, K.; Miya, M.; Azuma, Y.; Nishida, M. Independent Evolution of the specialized pharyngeal jaw apparatus in cichlid and labrid fishes. BMC Evol. Biol. 2007, 7, 10. [CrossRef] [PubMed]

25. Kimmerling, N.; Zuqert, O.; Amitai, G.; Gurevich, T.; Armoza-Zvuloni, R.; Kolesnikov, I.; Berenshtein, I.; Melamed, S.; Gilad, S.; Benjamin, S.; et al. Quantitative species-level ecology of reef fish larvae via metabarcoding. Nat. Ecol. Evol. 2018, 2, 306-316. [CrossRef] [PubMed]

26. Lakra, W.S.; Verma, M.S.; Goswami, M.; Lal, K.K.; Mohindra, V.; Punia, P.; Gopalakrishnan, A.; Singh, K.V.; Ward, R.D.; Hebert, P. DNA barcoding Indian marine fishes. Mol. Ecol. Resour. 2001, 11, 60-71. [CrossRef] [PubMed]

27. Bertrand, J.A.M.; Borsa, P.; Chen, W.J. Phylogeography of the sergeants Abudefduf sexfasciatus and A. vaigiensis reveals complex introgression patterns between two widespread and sympatric Indo-West Pacific reef fishes. Mol. Ecol. 2017, 26, 2527-2542. [CrossRef] [PubMed]

28. Zenetos, A.; Apostolopoulos, G.; Crocetta, F. Aquaria kept marine fish species possibly released in the Mediterranean Sea: First confirmation of intentional release in the wild. Acta Ichthyol. Piscat. 2016, 46, 255-262. [CrossRef]

29. Bariche, M.; Fricke, R. Dipterygonotus balteatus (Valenciennes, 1830) (Teleostei: Caesionidae), a new alien fish in the Mediterranean Sea. Bioinvasions. Rec. 2018, 7, 79-82. [CrossRef]

30. Bos, A.R.; Ogwang, J. Caesio varilineata Carpenter, 1987 (Osteichthyes: Caesionidae) a new alien fish in the southeastern Mediterranean Sea. Bioinvasions. Rec. 2018, 7, 441-445. [CrossRef]

31. Tiralongo, F.; Giovos, I.; Doumpas, N.; Langeneck, J.; Kleitou, P.; Crocetta, F. Is the Mangrove Red Snapper Lutjanus argentimaculatus (Forsskål, 1775) established in the eastern Mediterranean Sea? First records from Greece through a citizen science project. Bioinvasions. Rec. 2019, 8, 911-916. [CrossRef]

32. Filiz, H.; Sevingel, N.; Cerim, H.; Bilge, G. First record of the blackbar hogfish, Bodianus speciosus (Actinopterygii: Perciformes: Labridae), in the Mediterranean Sea. Acta Ichthyol. Piscat. 2019, 49, 399-402. [CrossRef]

33. Shakman, E.A.; Ben Abdalha, A.; Talha, F.; Al-Faturi, A.; Bariche, M. First records of seven marine organisms of different origins from Libya (Mediterranean Sea). Bioinvasions. Rec. 2017, 6, 377-382. [CrossRef]

34. Bazairi, H.; Sghaier, Y.R.; Benamer, I.; Langar, H.; Pergent, G.; Bourass, E.M.; Verlaque, M.; Ben Souissi, J.; Zenetos, A. Alien marine species of Libya: First inventory and new records in El-Kouf National Park (Cyrenaica) and the neighbouring areas. Mediterr. Mar. Sci. 2013, 14, 451-462. [CrossRef]

35. Shakman, E.A.; Eteayb, K.; Taboni, I.; Ben Abdalha, A. Status of marine alien species along the Libyan coast. J. Black Sea 2019, 25, 188-209.

36. Al-Mabruk, S.A.A.; Stoilas, V.O.; Kleitou, P.; Giovos, I. The first record of Torquigener flavimaculosus (Tetraodontiformes: Tetraodontidae) from Libya. Int. J. Fish. Aquat. Stud. 2018, 6, 449-450.

37. Rizgalla, J.; Fridman, S.; Ben Abdallah, A.; Bron, J.E.; Shinn, A.P. First record of the non-native sea snail Haminoea cyanomarginata Heller \& Thompson, 1983 (Gastropoda: Haminoeidae) in the Southern Mediterranean Sea. Bioinvasions. Rec. 2018, 7, 411-414. [CrossRef]

38. Rizgalla, J.; Bron, J.E.; Crocetta, F.; Shinn, A.P.; Almabruk, S.A.A. First record of Aplysia dactylomela Rang, 1828 (Mollusca: Gastropoda) in Libyan coastal waters. Bioinvasions. Rec. 2019, 8, 80-86. [CrossRef]

39. Rizgalla, J.; Shinn, A.P.; Crocetta, F. First documented record of the invasive cockle Fulvia fragilis (Forsskål in Niebuhr, 1775) (Mollusca: Bivalvia: Cardiidae) in Libya. Bioinvasions. Rec. 2019, 8, 314-319. [CrossRef]

40. Rizgalla, J.; Shinn, A.P.; Crocetta, F. New records of alien and cryptogenic marine bryozoan, mollusc, and tunicate species in Libya. Bioinvasions. Rec. 2019, 8, 590-597. [CrossRef]

41. Rizgalla, J.; Shinn, A.P.; Crocetta, F. The alien fissurellid Diodora ruppellii (G. B. Sowerby I, 1835): A first record for Libya from Tripoli Harbour. Bioinvasions. Rec. 2019, 8, 813-817. [CrossRef] 
42. Al Mabruk, S.A.A.; Rizgalla, J. First record of lionfish (Scorpaenidae: Pterois) from Libyan waters. J. Black Sea 2019, 25, 108-114.

43. Dragičević, B.; Anadoli, O.; Angel, D.; Benabdi, M.; Bitar, G.; Castriota, L.; Crocetta, F.; Deidun, A.; Dulčíć, J.; Edelist, D.; et al. New Mediterranean Biodiversity Records (December 2019). Mediterr. Mar. Sci. 2019, 20, 645-656.

44. Rizgalla, J.; Crocetta, F. First record of the fissurellid mollusc Diodora funiculata (Mollusca: Gastropoda) in Libyan waters (Gulf of Sidra, central Mediterranean Sea). Bioinvasions. Rec. 2020, 9. in press.

(C) 2019 by the authors. Licensee MDPI, Basel, Switzerland. This article is an open access article distributed under the terms and conditions of the Creative Commons Attribution (CC BY) license (http://creativecommons.org/licenses/by/4.0/). 